\title{
Hyperplastic Polyp? Look Again... The Impact of the New Classification for Serrated Polyps
}

\author{
Pólipo Hiperplásico? Olhe com Atenção... O Impacto da Nova Classificação \\ para os Pólipos Serreados
}

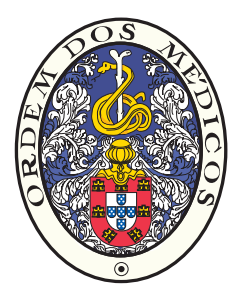

\author{
Catarina FIDALGO ${ }^{1}$, Liliana SANTOS 2 , Isadora ROSA ${ }^{1,3}$, Ricardo FONSECA ${ }^{2}$, Pedro LAGE ${ }^{1,3}$, Isabel CLARO ${ }^{1,3}$, Paula \\ CHAVES ${ }^{2}$, António DIAS PEREIRA ${ }^{1}$ \\ Acta Med Port 2014 May-Jun;27(3):304-308
}

\section{ABSTRACT}

Introduction: The World Health Organization reviewed the classification for serrated colonic polyps in 2010. A new entity, sessile serrated adenoma, was included with two variants: with and without cytological dysplasia. This lesion's malignant potential has been recognized and according to the new classification, many polyps may be reclassified. The impact of this change is yet to be assessed. Objective: Analyze the proportion of lesions that were reclassified according to the new World Health Organization classification and the variables that influenced it.

Material and Methods: Every patient with at least one sessile serrated adenoma diagnosed in a 5 year period was included. All polyps (regardless of type) resected during the study period were reviewed. Data concerning polyp's characteristics and patient variables were collected. Forty consecutive patients were included [13 female, mean age at $1^{\text {st }}$ sessile serrated adenoma -59 yrs (34-80)].

Results: Were reviewed 247 polyps: hyperplastic - 42\%; conventional adenomas - 29\%; sessile serrated adenoma - $24 \%$; serrated adenomas - $5 \%$. Sixty-three polyps were reclassified: 43 hyperplastic, 12 serrated adenomas, 7 sessile serrated adenoma and 1 conventional adenoma with low grade dysplasia. Reclassification was significantly greater for hyperplastic polyps when compared with the other subtypes. Forty-three of one hundred and four (41\%) hyperplastic polyps were reclassified all as sessile serrated adenoma. In these polyps the probability of reclassification was independent from polyp location but was greater if polyp size $\geq 5 \mathrm{~mm}$.

Discussion: This is a single center, rectrospective study. The fact that it was done in an Oncology Referral Institution with a Family Risk Clinic may have influenced the results. Nevertheless the impressive reclassification rate for Hyperplastic Polyps and the fact that they were reclassified mainly as Serrated Adenomas makes these results relevant to daily practice.

Conclusion: Our results suggest that, according to the new World Health Organization classification for serrated colonic polyps, a considerable proportion of hyperplastic polyps will be reclassified. The serrated pathway of colorectal carcinogenesis has probably been underestimated and at-risk patients may have been under inappropriate surveillance.

Keywords: Colonic Neoplasms/diagnosis; Colonic Polyps/classification; World Health Organization; Neoplasm Grading.

\section{RESUMO}

Introdução: A Organização Mundial de Saúde reviu a classificação para os pólipos serreados do cólon em 2010. Uma nova entidade, o adenoma serreado séssil, foi incluída com duas variantes: com e sem displasia citológica. O potencial de malignização desta lesão foi reconhecido e, de acordo com a nova classificação, muitos pólipos poderão ser reclassificados. O impacto desta mudança ainda não foi aferido.

Objectivo: Analisar a proporção de lesões reclassificadas de acordo com a nova classificação da Organização Mundial de Saúde e as variáveis que a influenciaram.

Material e Métodos: Todos os doentes com pelo menos um adenoma serreado séssil diagnosticado num período de cinco anos foram incluídos. Todos os pólipos (independentemente do tipo histológico) ressecados durante o período considerado foram revistos. Recolhidas variáveis dos pólipos e dados dos doentes. Incluídos 40 doentes consecutivos [13 mulheres, idade média no diagnóstico do $1^{\circ}$ adenoma serreado séssil - 59 anos (34-80)].

Resultados: Revistos 247 pólipos: hiperplásicos - 42\%; adenomas convencionais - 29\%; adenoma serreado séssil - 24\%; adenomas serreados-5\%. Reclassificados 63 pólipos: 43 hiperplásicos, 12 adenomas serreados, 7 adenoma serreado séssil e 1 adenoma convencional com displasia de baixo brau. A reclassificação foi significativamente mais provável para os pólipos hiperplásicos em relação aos outros subtipos. $41 \%$ (43/104) dos pólipos hiperplásicos foram reclassificados como adenoma serreado séssil. Para estes pólipos a probabilidade de reclassificação foi independente da localização mas maior se a dimensão $\geq 5 \mathrm{~mm}$.

Discussão: Este é um estudo rectrospectivo que foi conduzido num único Centro Oncológico de Referenciação com uma Clínica de Risco Familiar associada, o que pode ter influenciado os resultados. No entanto, a elevada taxa de reclassificação para os pólipos hiperplásicos e o facto de estes terem sido reclassificados quase sempre como adenomas serreados tornam estes resultados relevantes para a prática do dia a dia.

Conclusão: Os nossos resultados mostram que, de acordo com a nova classificação da Organização Mundial de Saúde para os pólipos serreados, uma proporção considerável de pólipos hiperplásicos seria reclassificada. A via serreada de carcinogénese colorectal tem sido provavelmente subestimada e doentes em risco podem estar sob vigilância inadequada.

Palavras-chave: Classificação de Tumores; Neoplasias do Colon/classificação; Neoplasias do Colon/diagnóstico; Organização Mundial de Saúde; Pólipos do Cólon.

\footnotetext{
1. Serviço de Gastrenterologia. Instituto Português de Oncologia de Lisboa Francisco Gentil, E.P.E. Lisboa. Portugal.

2. Serviço de Anatomia Patológica. Instituto Português de Oncologia de Lisboa Francisco Gentil, E.P.E. Lisboa. Portugal.

3. Clínica de Risco Familiar. Instituto Português de Oncologia de Lisboa Francisco Gentil, E.P.E. Lisboa. Portugal.

Recebido: 29 de Julho de 2013 - Aceite: 14 de Outubro de 2013 | Copyright @ Ordem dos Médicos 2014
} 


\section{INTRODUCTION AND OBJECTIVE}

Sporadic colorectal carcinogenesis is presently known to comprise several pathways. The time when only the suppressor and mutator pathways were known has passed. ${ }^{1}$ A new sequence to sporadic colorectal cancer (CRC) has been described, the serrated pathway, thought to give rise to about $20 \%$ of all sporadic CRCs. Molecular genetics has characterized two sequences of events leading to CRC in this serrated pathway: the more frequent one is initiated with an early mutation in BRAF and, through a mechanism of gene hypermethylation, known as $\mathrm{CpG}$ island methylator phenotype (CIMP), originates frequent MLH1 inactivation and CRCs with high-grade microsatellite instability (MSI-H). ${ }^{1}$ The precursor lesion in this serrated pathway is thought to be the sessile serrated adenoma (SSA), a unique lesion that exhibits architectural dysplasia and rarely true cytological dysplasia. This pathway is thought to give rise to $15 \%$ of all sporadic CRCs (Fig. 1). A less known and less frequent genetic sequence, involves early mutation in KRAS and a process of chromosomal instability, resulting in microsatelite stable CRCs, which are thought to represent $5 \%$ of all sporadic CRCs. The precursor lesion proposed for this sequence is the traditional serrated adenoma (TSA). ${ }^{2}$

In fact, the World Health organization (WHO) has acknowledge this by releasing a new classification for serrated polyps, that includes the hyperplastic polyp $(\mathrm{HP})$, the sessile serrated adenoma (SSA) with or without cytological dysplasia and the traditional serrated adenoma (TSA), all last three with recognized malignant potencial. ${ }^{3}$

The histological hallmark of the SSA is architectural dysplasia, meaning that there is a disordered growth with dilated crypts in the lower third compartment of the epithelium, with inverted T or L-shaped crypt bases ${ }^{3}$. SSAs are difficult to distinguish histologically from hyperplastic polyps and there is no known imunohistochemical stain that can help differentiate the two. ${ }^{4}$ Moreover, specimen orientation is crucial and piecemeal or forceps removal of these lesions further complicates classification. ${ }^{2}$ The SSA with cytological dysplasia is a much rarer lesion that not only exhibits architectural dysplasia but also has features of true cytological dysplasia (straight, elongated and hypercromatic nuclei in a basophile cytoplasm). SSA with dysplasia is thought to have a higher malignant potential and recent international recommendations state that it implies a follow up colonoscopy within three years. ${ }^{5}$ The same three year interval is now proposed for SSAs > $1 \mathrm{~cm} .{ }^{5}$ TSAs are very rare and less known, their cytological dysplasia exhibits pencil shaped nuclei in an eosinophilic cytoplasm. TSA is thought to be the precursor of a variant serrated pathway that, through chromosomic instability originates more distal microsatellite stable $\mathrm{CRCs}^{2}$ and present guidelines recommend a follow up colonoscopy three years after a TSA is resected. ${ }^{2,5}$

This new paradigm means that polyps formerly classified as hyperplastic or mixed lesions (those with both hyperplastic and adenomatous components), could be reclassified, implying that many individuals could have a different risk profile for CRC. In fact, according to this new knowledge many patients may have been under unsuitable surveillance protocols. The magnitude of the impact of the reclassification needs to be assessed.

The objectives of the present study were to determine the proportion of reclassified lesions in a population with

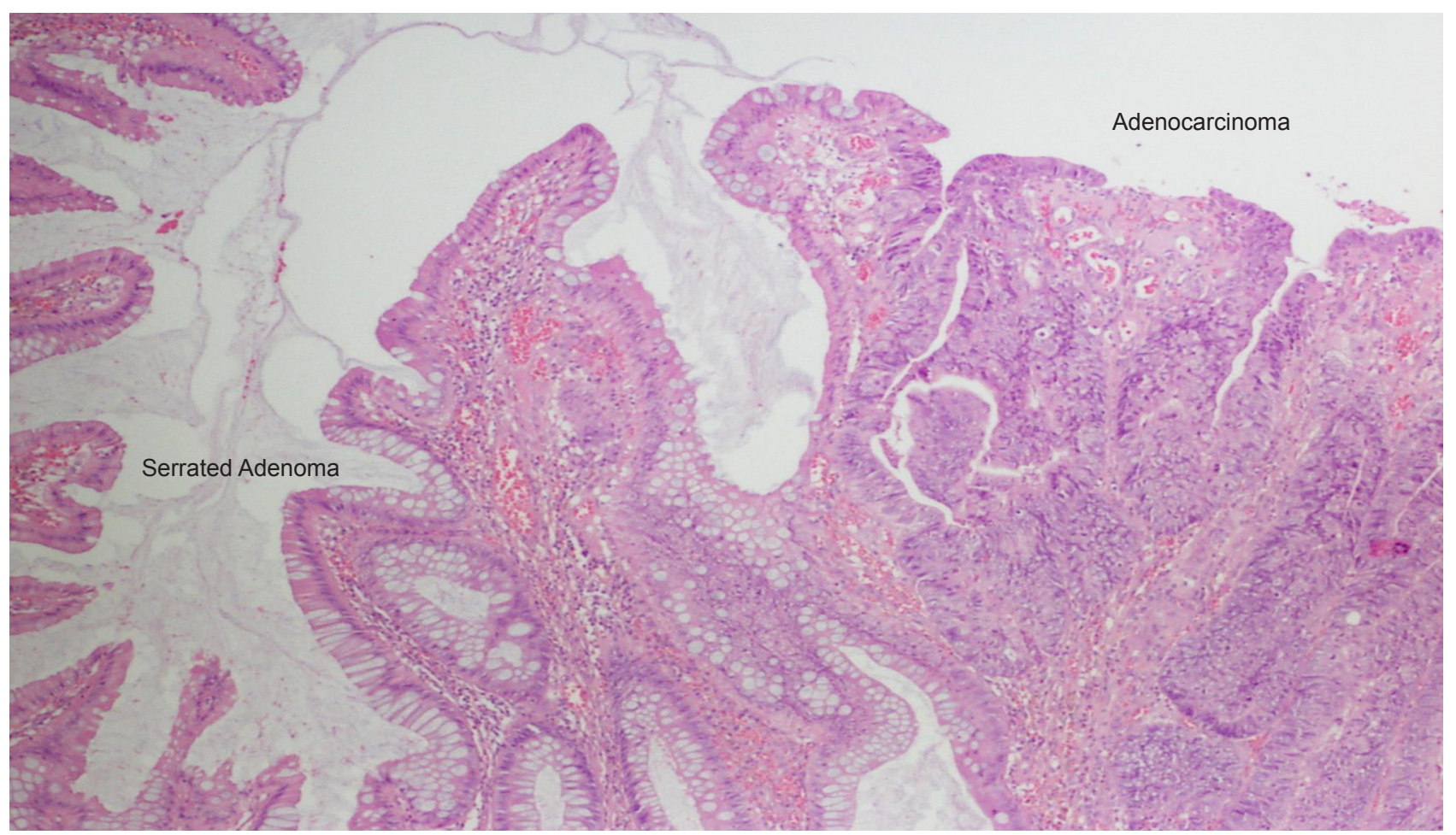

Figure 1 - Transition between serrated adenoma and adenocarcinoma (H\&E stain). 
at least one SSA, in light of the new WHO classification for serrated polyps, and assess the features that influenced the likelihood of reclassification.

\section{MATERIAL AND METHODS}

All patients with at least one SSA resected during a five year period (January 2006 to December 2010) were included. All the polyps removed from these patients (irrespective of histology) were reviewed by two pathologists, one of them expert on gastrointestinal pathology. Whenever difference in opinion occurred, agreement was reached by consensus. The lesions were classified as serrated polyps (HP, SSA, TSA) or conventional adenomas (tubular, tubulovillous, villous). Data regarding polyp size, location and histology were collected, as well as patient gender, age and familial risk for CRC. The right colon was defined as any segment proximal to the splenic flexure (cecum, ascending and transverse colon). Polyps from patients with Serrated Polyposis Syndrome (SPS) formerly known as Hyperplastic Polyposis Syndrome were included in this study. Statistics were performed with SPSS ${ }^{\circledR} 19\left(\mathrm{Chi}^{2}\right.$ and Fisher Exact Test). All $p$ values were considered significant when $<0.05$.

\section{RESULTS}

Forty patients were selected, according to the criteria previously defined, and a total of 247 polyps were revised. Patient's characteristics are summarized in Table 1 and the histological classification before revision is illustrated in Table 2.

It must be noticed that some of the new categories for serrated polyps were used previously to the new WHO classification for serrated polyps as some of our pathologists were already familiarized with these new lesions.

From the 247 reviewed lesions, 63 polyps were reclassified. The vast majority of reclassified lesions was before considered to be hyperplastic polyps and became SSA in light of the new WHO classification for serrated polyps. All the reclassifications are depicted in Table 3.

Thirty of forty patients $(75 \%)$ had at least one reclassified lesion. None of the conventional adenomas shifted to the serrated category and only one SSA became reclassified as a hyperplastic polyp. This contrasts with the major shift from hyperplastic polyps to sessile serrated adenomas, corresponding to $41 \%$ of all polyps previously classified as hyperplastic.

\section{Table 1- Patient's characteristics}

\section{Patient number}

Female gender

Mean age at $1^{\text {st }}$ SSA diagnosis (years - range)
$59(34-80)$

\section{Number of revised polyps}

247

${ }^{*}$ No family history of CRC or colonic adenomas; ${ }^{* *}$ Family history of CRC or colonic adenomas without known hereditary CRC; ${ }^{* * *}$ Known hereditary CRC syndrome (Familial
Adenomatous Polyposis, Lynch Syndrome or MUTYH-associated polyposis); ${ }^{* * * *}$ Fulfillment of the WHO criteria for Serrated Polyposis Syndrome (at least five serrated polyps proximal to the sigmoid colon, two of which are greater than $10 \mathrm{~mm}$ in diameter; any number of serrated polyps occurring proximal to the sigmoid colon in an individual who has a first-degree relative with serrated polyposis; or more than 20 serrated polyps of any size distributed throughout the colon).

Table 2 - Histological type before and after the reclassification

\begin{tabular}{llll}
\hline \multicolumn{2}{c}{ Before reclassification } & & After reclassification \\
\hline Hyperplastic polyp & $104(42 \%)$ & Hyperplastic polyp & $62(25 \%)$ \\
Sessile serrated adenoma & & Sessile serrated adenoma without dysplasia & $97(39 \%)$ \\
& $59(24 \%)$ & Sessile serrated adenoma with dysplasia & $10(4 \%)$ \\
Serrated adenoma* & $12(5 \%)$ & Traditional serrated adenoma & $4(2 \%)$ \\
Conventional adenoma & $72(29 \%)$ & Conventional adenoma & $74(30 \%)$ \\
\hline${ }^{*}$ All reports that classified lesions as Serrated adenomas made mention to low grade dysplasia.
\end{tabular}


All serrated adenomas were reclassified as this designation is not used in the new classification. Also worthy of note, is the fact that the majority of these lesions became reclassified as lesions with cytological dysplasia (three SSAs with dysplasia; four TSA and one tubular adenoma). It is not surprising that the majority of serrated adenomas were reclassified as lesions with cytological dysplasia) taking into account that initial reports made mention to low grade dysplasia.

When analyzing the variables that influenced the likelihood of reclassification, it was found that a polyp formerly classified as hyperplastic had a higher probability to be reclassified when compared to other histological types $(p<0.001)$. Polyp location did not influence the likelihood of reclassification but size did matter, as polyps $>5 \mathrm{~mm}$ were more prone to be reclassified as SSA $(p=0.03)$. It is important to point out that the presence of a Serrated Polyposis Syndrome diagnosis did not influence the probability of reclassification (Table 4).

\section{DISCUSSION}

To our knowledge only one paper has analyzed the proportion of reclassified lesions in light of the new WHO nomenclature. Singh et $\mathrm{al}^{6}$ reported that $11.8 \%$ of polyps previously classified as HPs turned out to be reassessed as sessile serrated adenomas, and right side location and size $>5 \mathrm{~mm}$ were the two variables that independently increased the probability of reclassification.
Our study reports an impressive proportion of reclassification, corresponding to $26 \%$ of all lesions. The major reassessment shift was from HPs to SSAs with or without dysplasia, as $43 / 63(68 \%)$ of the lesions that changed category were HPs that turned to SSAs. We found that a size $>5 \mathrm{~mm}$ was a significant variable but we did not find statistical significance for polyp location.

It is important to stress that our inclusion criteria implied each individual had at least one SSA diagnosed during the considered time period and this may mean these patients have a different probability of polyp reclassification (most likely an increased probability of reclassification). It must also be emphasized that although all polyps were reviewed by two Pathologists (one of them an expert in GI Pathology) this was not a blind agreement study. This was a retrospective unicentric study from an Oncology Institute that comprises a CRC Family Risk Clinic, meaning there may have been a selection bias. In fact, from the total 40 patients, $41 \%$ had some kind of increased CRC family risk profile and 8 of those fulfilled criteria for Serrated Polyposis Syndrome. Nevertheless, polyps changed classification in $30 / 40$ patients with or without increased family risk, and the presence of Serrated Polyposis Syndrome did not influence the probability of reclassification. This is to our knowledge the first study to assess the new WHO classification for serrated polyps in patients with this syndrome.

It is worthy of note that this impressive proportion of reclassification of HP was found in a referral Institution,

Table 3 - Lesion reclassification according to new WHO classification for serrated polyps

\section{AFTER RECLASSIFICATION}

\begin{tabular}{|c|c|c|c|c|c|c|c|}
\hline & & $\begin{array}{l}\text { Hyperplastic } \\
\text { polyp }\end{array}$ & $\begin{array}{l}\text { SSA without } \\
\text { dysplasia }\end{array}$ & $\begin{array}{l}\text { SSA with } \\
\text { dysplasia }\end{array}$ & $\begin{array}{l}\text { Traditional } \\
\text { Serrated } \\
\text { Adenoma }\end{array}$ & $\begin{array}{l}\text { Tubular } \\
\text { Adenoma }\end{array}$ & $\begin{array}{c}\text { Villous and } \\
\text { Tubulo- } \\
\text { villous } \\
\text { Adenoma }\end{array}$ \\
\hline \multirow{5}{*}{ 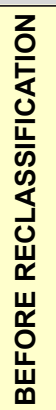 } & Hyperplastic & 61 & 41 & 2 & 0 & 0 & 0 \\
\hline & SSA & 1 & 52 & 5 & 0 & 1 & 0 \\
\hline & $\begin{array}{c}\text { Serrated } \\
\text { adenoma }\end{array}$ & 0 & 4 & 3 & 4 & 1 & 0 \\
\hline & $\begin{array}{l}\text { Tubular } \\
\text { Adenoma }\end{array}$ & 0 & 0 & 0 & 0 & 58 & 1 \\
\hline & $\begin{array}{l}\text { Villous and } \\
\text { Tubulo-villous } \\
\text { Adenomas }\end{array}$ & 0 & 0 & 0 & 0 & 0 & 13 \\
\hline
\end{tabular}

Table 4 - Variables that influenced reclassification

Hyperplastic vs other histological types

$$
\begin{aligned}
& p<0.001 \\
& p=0.21 \\
& p=0.03 \\
& p=0.54
\end{aligned}
$$$$
\text { Size }>5 \mathrm{~mm}
$$

\footnotetext{
*Serrated Polyposis Syndrome's WHO criteria (see footnote on Table 1).
} 
with a past and present interest for the serrated pathway, which can mean that the proportion of reclassified lesions may be greater in other Institutions. This means that many patients discharged from endoscopic follow up (based on hyperplastic histology) could be under inadequate surveillance. These concerns are underlined by the fact that the serrated pathway is presently thought to explain great part of the interval cancer phenomenon. ${ }^{7}$ It might be argued that it would be an enormous effort to revise all hyperplastic polyps from our patients, but it can be proposed that a past history of hyperplastic polyps, especially $>5 \mathrm{~mm}$ should pressure the clinician to anticipate the next colonoscopy from the formerly recommended 10 year schedule. ${ }^{5}$

\section{CONCLUSION}

Awareness of Gastroenterologists and Pathologists must be raised around the relevance of serrated colonic polyps. The new nomenclature must be incorporated into daily practice as this is not a marginal issue. The proportion of previously reported HPs that are now considered SSA seems to be between 10 and $40 \%$, which could change $\mathrm{CRC}$ risk profile and surveillance protocol in a substantial part of the population.

\section{CONFLICTS OF INTEREST}

The authors declared no conflicts of interest.

\section{FUNDING SOURCES}

This original work was not financed in any way.

\section{REFERENCES}

1. Al-Sohaily, Biankin A, Leong R, Kohonen-Corish M, Warusavitarne J. Molecular pathways in colorectal cancer. J Gastroenterol Hepatol. 2012;27:1423-31.

2. Huang C, Farraye F, Yang S, O'Brien MR. The clinical significance of serrated polyps. Am J Gastroenterol. 2011;106:229-40.

3. Snover D, Ahnen DJ, Burt RW, Odze RD. Serrated polyps of the colon and rectum and serrated polyposis. In: Bosman FT, Carneiro F, Hruban $\mathrm{RH}$, Theise ND, editors. WHO Classification of Tumours of the Digestive System. LYON: IARC Press; 2010. p. 134-46.

4. Gibson JA, Hahn HP, Shahsafaei AA, Odze RD. MUC expression in hyperplastic and serrated colonic polyps: lack of specificity of MUC6. Am J Surg Pathol. 2011;35:742-9.

5. Lieberman D, Rex D, Winawer S, Giardiello FM, Johnson DA, Levin TR. Guidelines for colonoscopy surveillance after screening and polypectomy: a consensus update by the US Multi-Society Task Force on Colorectal Cancer. Gastroenterology. 2012;143:844-57.

6. Singh H, Bay D, Ip S, Bernstein CN, Nugent Z, Gheorghe R, et al. Pathological reassessment of hyperplastic colon polyps in a city-wide pathology practice: implications for polyp surveillance recommendations. Gastrointest Endosc. 2012;76:1003-8.

7. Kahi CJ, Hewett DG, Norton DL, Eckert GJ, Rex DK. Prevalence and variable detection of proximal colon serrated polyps during screening colonoscopy. Clin Gastroenterol Hepatol. 2011;9:42-6. 


\section{Hyperplastic Polyp? Look Again... The Impact of the New Classification for Serrated Polyps Acta Med Port 2014:27:304-308}

Publicado pela Acta Médica Portuguesa, a Revista Científica da Ordem dos Médicos

Av. Almirante Gago Coutinho, 151

1749-084 Lisboa, Portugal.

Tel: +351218428215

E-mail: submissao@actamedicaportuguesa.com

www.actamedicaportuguesa.com

ISSN:0870-399X | e-ISSN: 1646-0758

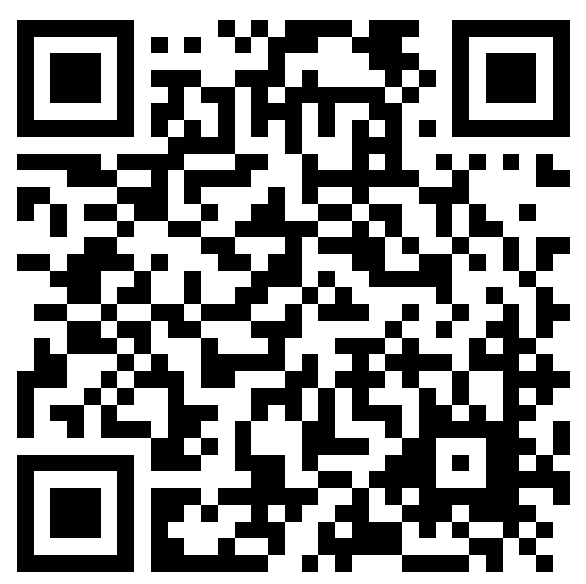

